\title{
Philosophy (and Wissenschaft) without Politics? Schlick on Nietzsche, German Idealism, and Militarism
}

[Final draft. Please cite version published in Christian Damböck \& Adam Tamas Tuboly (eds.), The Socio-Ethical Dimension of Knowledge: The Mission of Logical Empiricism (Vienna Circle Institute Yearbook). Basel: Springer.]

Andreas Vrahimis

Department of Philosophy

University of Cyprus

vrahimis.andreas@ucy.ac.cy

\begin{abstract}
With the outbreak of the First World War in 1914, there emerged two controversies related to the responsibility of philosophical ideas for the rise of German militarism. The first, mainly journalistic, controversy concerned the influence that Nietzsche's ideas may have had on what British propagandists portrayed as the ruthlessly amoral German foreign policy. This soon gave way to a second controversy, waged primarily among academics, concerning the purportedly vicious political outcomes of German Idealism, from Kant through to Fichte, Schelling, and Hegel. During the autumn of 1914, and at the cusp between the two controversies, Moritz Schlick was to deliver a lecture series on Nietzsche's life and work at the University of Rostock. Responding to both debates, Schlick penned an introduction in which he sought to defend philosophy against all those who would embroil it in warfare. Schlick offers a series of arguments defending Nietzsche against his accusers. He also argues that, though their contributions to the History of Philosophy often amounted to no more than 'beautiful nonsense', the German Idealists' philosophical views cannot be held responsible for the rise of German nationalism. Finally, Schlick mounts a general defense of the search for truth, both in philosophy and in Wissenschaft, as a type of activity which presupposes peace. Though Schlick's metaphilosophical views change, as this paper shows, he remains constant both in his favourable appraisal of Nietzsche, as well as his separation between politics on the one hand, and both philosophy and Wissenschaft on the other hand.
\end{abstract}

Keywords: Moritz Schlick; Vienna Circle; Nietzsche; Militarism; German Idealism 


\section{XY.1. Introduction ${ }^{1}$}

The Vienna Circle's conception of the relation between their philosophical work and their politics has been the subject of an ongoing debate. ${ }^{23}$ Recent work has primarily focused on the so-called 'left' faction of the Circle, often aiming to demonstrate the falsehood of an older stereotype of Logical Empiricism as apolitical. ${ }^{4}$ But what exactly was it that motivated those within the Circle who wanted to divorce philosophy from politics? In this chapter, I will specifically direct my attention to Moritz Schlick's views on the relation between philosophy and politics. ${ }^{5}$ In an attempt to shed further light on this topic, I will look to a rare instance, at the outset of the First World War, in which Schlick defended his attempt to demarcate between politics and philosophy.

The most important sources relevant to this are Schlick's notes for his lecture course on Nietzsche, which he had presented at the University of Rostock between 1912 and 1923; the notes were published for the first time in 2013. Having first presented his lecture course on Nietzsche in 1912, it was planned that Schlick would present it again during the winter semester in 1914 (see Iven 2013b, pp. 67-68). An obstacle to this plan arose when the First World War broke out. There is inadequate evidence for determining whether the course was cancelled due to the war or not. Nonetheless, Schlick had prepared an addendum to his 1912 notes, in which he specifically responds to two controversies concerning the relation between, on the one hand, the militarist attitude prevalent in Germany during the war, and, on the other hand, the philosophical work of Nietzsche, at first, and then of the German Idealists.

This chapter will open with a very brief overview of the Nietzsche controversy in the popular press, showing how it was soon displaced by an academic controversy concerning the

\footnotetext{
${ }^{1}$ In the summer of 2019, I presented some of the ideas that eventually developed into this paper at the annual conference of the Society for the Study of the History of Analytical Philosophy, held at Boston University, and at the TiLPS History of Analytic Philosophy workshop, held at Tilburg University; I am thankful to all those present for their many useful comments, suggestions, and encouragement. I owe thanks to Mathias Iven for reading and commenting on a draft of this chapter. For their many helpful suggestions and overall editorial contributions, I am especially grateful to Christian Damböck and Adam Tamas Tuboly.

${ }^{2}$ All translations from the German sources, without a previous English translation, are mine.

${ }^{3}$ E.g. Mulder (1968); Stadler (1982) and (1991); Cartwright, Cat, Fleck and Uebel (1996); Uebel (2005), (2008), (2012); Romizi (2012); and Tuboly (2020a).

${ }^{4}$ The existence of a uniform 'left' Vienna Circle was recently disputed by Richardson (2009a) and (2009b) and defended by Uebel (2010). For an account of the role subsequently played by McCarthyism in this depiction, see Reisch (2005). On an altogether different front, Horkheimer ([1937] 1972) had played an important role in disseminating the miscomprehension of the Vienna Circle as apolitical; see e.g. Dahms (1994); O'Neil and Uebel (2004); and Vrahimis (2020a).

${ }^{5}$ As Mormann (2010, pp. 263-264) notes, Schlick’s early work has remained, until relatively recently, understudied. Apart from the excellent editorial work involved in the publication of Schlick's Gesamtausgabe (e.g. Iven 2013a and 2013b), other recent studies that consider the early Schlick include Siegetsleitner (2010), Ferrari (2016), Textor (2018), as well as Tuboly's and Ambrus' chapters in this volume.
} 
responsibility of German Idealism for the war. ${ }^{6}$ This allows us to situate Schlick's 1914 addendum to his Nietzsche lectures as a response to both controversies. Having examined Schlick's defence of Nietzsche against his interpretation as a militarist in 1914, I will turn to Schlick's development of a similar defense in Natur und Kultur. As we shall see, Schlick remains constant in his appreciation of Nietzsche even when he denounces fascistic attempts to employ his work as a justification for waging unrestricted war between nations.

Connecting the two 1914 controversies, Schlick holds that it is contradictory to blame both Nietzsche and German Idealism for Germany's wartime aggression. Schlick has some highly critical things to say about the Idealist system-builders and their preference for 'beautiful nonsense' over scientific facts. Regardless of Schlick's estimation of their philosophical worth, he maintains that a clear line can and must be drawn between their philosophy and their political rhetoric. As I shall demonstrate, Schlick's response to both controversies relies on an overall conception of the value of Wissenschaft (of which philosophy is part) that runs throughout his work. This conception underlies Schlick's argument that philosophy presupposes peace, and cannot be put to use for the purposes of waging war.

\section{XY.2. The Nietzsche Controversy in the Popular Press}

On June 28 1914, Gavrilo Princip assassinated Archduke Frantz Ferdinand, soon leading to the outbreak of the First World War. Scrutinizing Princip's background, the contemporary popular press discovered a secret society called the Black Hand, which they depicted as being responsible for the assassination. Allegedly, the Black Hand were inspired by the writings of a German philosopher named Friedrich Nietzsche, and they would even begin their secret meetings by reciting some of his poetry (Martin 2006, pp. 147-148). This set the wheels in motion for a subsequent controversy concerning the connection between Nietzsche's philosophy and the war.

With the United Kingdom's entry into the war effort on August 4, Nietzsche's philosophical work would become one of the chief targets of the British press. ${ }^{7}$ Nietzsche was declared to be the mastermind behind amoral German militarism and imperialism (see, e.g., Martin 2006). The propagandists would caricature Nietzsche as directly responsible for German aggression and the brutal tactics employed in the burning of Louvain. They

\footnotetext{
${ }^{6}$ For a more extended analysis of these controversies, see e.g. Hoeren (2004); Akehurst (2010); Vrahimis (2015) and Jeffs (2017).

${ }^{7}$ On the parallel Franco-German controversy over Nietzsche within Catholic theology, see Köster (1998, ch. V).
} 
identified a transmission of his thought through the influence of the historian Heinrich von Treitschke, ${ }^{8}$ as well as Friedrich von Bernhardi, a general and writer on military matters.

Nietzsche was presented as having taught the 'mandarins' of the German state the lesson that politics is an expression of the will to power, a game in which morality (and especially Christian slave-morality) constitutes a mere hindrance to success. ${ }^{9}$ Nietzsche's influence was by no means portrayed as limited to policy-makers: it was rumored that German soldiers went to war with a copy of Zarathustra in their knapsacks (as opposed to British soldiers with their Bibles). ${ }^{10}$ The author of the Antichrist was even sometimes portrayed as the devil (Martin 2006, p. 153). ${ }^{11}$

In his academic estimation of Nietzsche's influence on the war published in 1915, H. L. Stewart, Professor of Philosophy at Dalhousie University, would describe the debate in the popular press as follows:

\begin{abstract}
Newspapers and magazines have been filled with estimates which may well bewilder the public. One critic declares that chapter and verse may be quoted from Zarathustra to justify every step which Germany has taken; another finds that no philosopher has spoken out more boldly against the spirit of racial aggressiveness that, in short, Nietzsche is the champion of the German Geist, not as embodied in, but as contrasted with, the German Reich. In the heated language of the moment there is, of course, much exaggeration and much misunderstanding. (Stewart 1915, p. v)
\end{abstract}

Interestingly, as Stewart notes, the controversy had included various attempts to answer the British propagandists' claims about Nietzsche's responsibility for the war. Stewart nonetheless dismisses such views as serving the interests of "German apologists" (1915, p. 150), who would rather "disown" Nietzsche than have their real beliefs made public internationally.

Despite purporting to give a disinterested scholarly take on the debate that would avoid the fallacies of the wider public, which "loves to fix odium upon an individual" (1915, p. 153), Stewart soon falls into analogous journalistic tropes. Though he admits that

\footnotetext{
${ }^{8}$ For a discussion of Treitschke's debates with Dilthey (in the broader context of the development of Logical Empiricism) see Damböck (2017, pp. 99-106).

${ }^{9}$ I borrow the term 'mandarin' here from the title of Ringer's (1969) famous work.

${ }^{10}$ As Martin (2006, pp. 154-155) points out, publishers at the time did issue pocket-sized versions (intended for soldiers) of the bible and various literary and philosophical works, including Nietzsche's Zarathustra, as well as anthologies of his sayings about war. It should be noted that the existence of this industry partly explains the proliferation of wartime writings by philosophers, since many such works were intended to be printed and disseminated in this form. (For this insight, I am grateful to Bernie Linsky who mentioned to me that Wundt's Die Nationen und ihre Philosophie was printed in this way.)

${ }^{11}$ Martin (2006, p. 153) shows that this description was used in Britain as a marketing strategy to sell Nietzsche's books.
} 
philosophy rarely has the public influence that is attributed to Nietzsche, he expressly rejects the claim that Nietzsche was not influential in Germany. As evidence of Nietzsche's influence, he cites his verbal conversations with "a British critic, very familiar with Continental philosophy" (1915, p. 150) and a German professor, both unnamed, who told him that Nietzsche is constantly talked about "in educated circles" (1915, p. 151). Stewart (1915, p. 155) acknowledges the view that Nietzsche was in fact an individualist, but claims that this leads him towards idolizing ruthless warriors (1915, p. 159). He sees that Nietzsche criticized "the rising military spirit" (1915, p. 155) which threatened to undermine German civilization, but he insists that Nietzsche had no great love for civilization and was delighted by its destruction (1915, pp. 160-161). ${ }^{12}$ Stewart sees that Nietzsche valued cosmopolitanism and despised nationalism (1915, pp. 156-157); yet behind his cosmopolitanism, according to Stewart, is an imperialistic effort to establish an internationally 'dominant "exploiting" class' $\left(1915\right.$, p. 161). ${ }^{13}$ He detects a Nietzschean "immoralism" as the underlying principle guiding the foundation and running of the German state:

\begin{abstract}
What the statesmen of Berlin had for generations been whispering into one another's ears in secret Nietzsche has proclaimed upon the housetops; he inspired the thought that the unscrupulous selfishness which Prussia had plainly practised [sic], and the ruthlessness which had marked the campaigns of her troops, were not something to be ashamed of, but something to be gloried in; he cast the halo of an intellectual vindication round the methods of aggression which the bureaucracy had followed, but which they had for merely thought it desirable to mask before the public opinion of Europe. (Stewart 1915, p. 171)
\end{abstract}

The above passage illustrates the floundering of Professor Stewart's supposedly 'scholarly' attempt to avoid the excesses of the popular press that he decries. It is perhaps unsurprising that Stewart's effort to give the popular controversy over Nietzsche a kind of academic veneer was not further discussed during the war. ${ }^{14}$

\title{
XY.3. The Academic Controversy about German Idealism
}

\footnotetext{
${ }^{12}$ Interestingly, as we shall see, Schlick's defenses of Nietzsche (both in 1914 and during the 1930s) raise the three points Stewart would reject: he rejects the idea that Nietzsche was influential in Germany, he insists on interpreting Nietzsche as an individualist, and on this basis he rejects the view that Nietzsche valued war among states.

${ }^{13}$ In support of this view, Stewart (1915, p. 163) mentions the specific interpretations of Nietzsche as a militarist that Schlick would vehemently argue against, namely the idea that States are locked in a perpetual struggle for dominance.

${ }^{14}$ Voegelin (1944, p. 177) briefly refers to Stewart in his discussion of Nietzsche's relation to the next war.
} 
Apart from Stewart's unwarranted rhetorical flourishes, there is a better explanation as to why the Nietzsche controversy was not widely addressed by academics. The controversy, which took place in newspapers at the early stages of the war in 1914, soon gave way to a second, academic controversy that would continue throughout the war.

Contrary to Stewart's claims, Nietzsche had been a relatively minor figure in the contemporary academic philosophical establishment, whether Germanophone or not. ${ }^{15}$ Rather than Nietzsche, contemporary international academic philosophical debate was primarily concerned with various brands of Idealism. ${ }^{16}$ In the wake of Kant, this had been a product that Germanophone academia had successfully exported throughout the world. At the time, most of the Philosophy Departments of the Universities of the key players involved in the war (including Britain, France, the United States and Germany) had been dominated by Idealists of one sort or other. ${ }^{17}$ After the end of the war, most of these Idealist schools would be in decline. In large part this was due to their participation in the wartime controversy, as the Professors' enthusiasm for the war in 1914 would be hard to justify after $1918 .^{18}$

The controversy can be traced back to a declaration by a number of British authors who, in response to the German offensive on Belgium, defended England's entry into the war. On October 4, 1914, there came an answer signed by 93 German Professors attempting to justify Germany's participation in the war. ${ }^{19}$ Their defense closes with a promise that

we shall carry on this war to the end as a civilized nation, to whom the legacy of a Goethe, a Beethoven, and a Kant is just as sacred as its own hearths and homes. ("Professors of Germany", 1919, p. 285)

\footnotetext{
${ }^{15}$ Nietzsche did begin to appeal to popular audiences before the war, and he had considerable influence over various social movements; see e.g. Thomas (1983) and Akehurst (2010, p. 20).

${ }^{16}$ Nevertheless, as Damböck (forthcoming) highlights, the influence of post-Kantian Idealism in nineteenth German philosophy was exaggerated by later figures (such as Heidegger) who underemphasized other developments in German philosophy after Hegel's death.

${ }^{17}$ As Akehurst (2010, pp. 18-19) notes, for example, despite the fatal blow they had earlier received from Moore's and Russell's philosophical objections, in 1914 the British Idealists were still a leading force in British academic and political institutions. (The impact of Idealism on Anglophone academia would long continue to be felt even outside philosophy, for example in the philosophical writings of physicists like Eddington, and later Jeans.) In fact, German Universities were at the forefront of international academia before the war, and it was only Germany's defeat that tipped the scales towards Anglophone Universities; see e.g. Windsor (2014).

${ }^{18}$ On the aftermath of these debates, see e.g. Ringer (1969, esp. Ch. 4); Kusch (1995, pp. 224-271); Vrahimis (2015) and Reynolds (2017).

${ }^{19}$ It should be noted that, though Schlick was not among the ninety-three Professors, he did sign the declaration of October 16, 1914, produced by Ulrich von Wilamowitz-Moellendorf and Dietrich Schäfer, and signed by more than three thousand German teachers and professors (which included all of the teachers in his University); see Iven (2008; 2013a, pp. 30-32); Wolters (2017, 11-13; Forthcoming).
} 
The reference to Kant led to a subsequent international debate about whether he and the postKantian Idealists were somehow responsible for the development of German militarism. Illustrating the shift that took place from one controversy to the next, a New York Times review of Dewey's 1915 German Philosophy and Politics states:

\begin{abstract}
Not Nietzsche, but Immanuel Kant is responsible for the spirit of twentieth century Germany. Not belief in the superman but belief in the categorical imperative and the thing-in-itself has sent Germany to war with the world. Not Thus Spoke Zarathustra but the Critique of Pure Reason explains the amazing utterances of Bernhardi, of Treitschke, of Wilhelm himself. (Anonymous, p. 1915)
\end{abstract}

Dewey, Bergson, Boutroux, L.T. Hobhouse, F.C.S. Schiller, and other philosophers would become embroiled in a debate as to whether the war justifies a severing of all ties with Germanophone philosophy, whose malevolent influence it purportedly exemplifies. Amongst the German Neo-Kantians, we find figures like Hermann Cohen, Paul Natorp, and Alois Riehl attempting to justify Germany's involvement in the war on the grounds of the superiority of German Kultur (a concept which they trace back to Kant) over the mere civilizations of the rest of Europe. ${ }^{20}$

I will avoid providing further details concerning these philosophers' perplexing and complex attempts to fight the war by means of their arguments and theses, limiting myself instead to the mention of two facts about this controversy insofar as they are relevant to Schlick's response. First of all, for the purposes of this study, it is important simply to note, as I already have, that this controversy followed after the Nietzsche controversy in 1914. Schlick, as we will go on to see, responded to the Idealism controversy at its very early stages, before the publication of extended analyses of Idealism developed by some of the abovementioned philosophers. He thus does not consider it in its details; primarily, Schlick is concerned with rejecting the central claim that the philosophies of Kant, Fichte, Schelling, or Hegel are somehow responsible for militarism. Secondly, the international debate did not only pit Idealists against their critics, but also led to internal tensions among the various schools that claimed to be continuations of the German Idealist legacy. If they were to avoid the accusation of betraying their nations, Idealists on either side of the war needed to defend opposite views. While the Idealist schools in Germany tended to portray the legacy of

\footnotetext{
${ }^{20}$ See Vrahimis (2015); Beiser (2018, 300-304). Like many German academics at the time, Schlick opposed culture to civilization in his early work; see Mormann (2010, pp. 268-269). Outside the Neo-Kantian mainstream, other German philosophers prominently engaged in wartime propaganda included Wilhelm Wundt and Max Scheler; see Kusch (1995, pp. 211-224); see also de Warren and Vongehr (2018).
} 
idealism as supporting German wartime politics, the defenders of Idealism in the rest of the world tended to demarcate between philosophy and its application to politics (Vrahimis 2015, pp. 91-92). Within the Germanophone context, the kind of divorcing of philosophy from militarist politics that Schlick advocated was in line with his overall anti-Idealistic stance. Yet outside the Germanophone context, Schlick's position is aligned with defenders of Idealism who proclaimed the political neutrality of its strictly speaking philosophical content, and thereby its innocence as far as the war is concerned.

\section{XY.4. Nietzsche's Influence on Schlick}

Schlick had encountered Nietzsche's work both quite early on in relation to his own intellectual development, and also at a very early stage in the history of the reception of Nietzsche's thought (Iven 2013a, 2013b). Nietzsche had not yet died in 1898 when the 16year-old Schlick discovered his works. Like many adolescents after him, Schlick enthusiastically read Zarathustra, having read very little philosophy before that (Iven 2013b, p. 55). He would later note in his unpublished autobiography that during his lifetime no other book would "so shake and enrapture [him] as much as Zarathustra" (quoted in Iven 2013a, p. 18), while elsewhere he thanks Nietzsche for causing in him "so many tears of high enthusiasm" (quoted in Iven 2013a, p. 18). Schlick's unpublished (and undated) writings even include his attempt at emulating Nietzsche's language in a prose poem consisting of a dialogue with Zarathustra (Iven 2013b, p. 63). Traces of Nietzsche's style can be found throughout Schlick's less technical work, from the 1908 Lebensweisheit to his posthumously published Aphorismen.

Before the 1912 lectures, the influence of Nietzsche is chiefly felt in Lebensweisheit (Ferrari 2016). I shall return towards the end of this chapter to Schlick's account of the way in which, in Schlick's reworking of Nietzsche's 'will to power', scientific knowledge [Wissenschaft] is connected to the 'will to pleasure' [Wille zur Lust] and the 'will to truth' [Wille zur Wahrheit]. As I will outline in Sections XY.8 and XY.9, this Nietzschean account will later constitute a central aspect of Schlick's conceptions of epistemology and metaphilosophy, and thus of his account of the relation between philosophy and politics.

Given the above, it should not be surprising that Schlick chose Nietzsche as the topic of his lectures at the University of Rostock in 1912. Before moving on to analyze Schlick's introduction to the Nietzsche lectures penned in 1914, two things must be noted concerning the content of Schlick's 1912 notes. 
First, a note should be made on the methodology of Schlick's lectures. Interestingly, Schlick takes a kind of Nietzschean approach to his presentation of Nietzsche, insofar as he intertwines his account of the thinker's life with an account of his philosophy. In order to make sense of Nietzsche's oeuvre, Schlick's lectures explore biographical details, e.g. concerning Nietzsche's health, his relations to his family and friends, his various travels. Schlick (2013a, pp. 102-103) in fact argues that such an account is indispensable to understanding Nietzsche's work. In one of many examples of Schlick's approach, he explains how Nietzsche's choice of an aphoristic style was dictated by the state of his health, which only allowed him to concentrate on writing, aided by an amanuensis, for limited spans of time (Schlick 2013a, pp. 240-242). ${ }^{21}$

Secondly, perhaps the most important aspect of Schlick's lectures is the way in which it presents Nietzsche's relation to positivism. Schlick divides Nietzsche's work into three phases: (i) an early metaphysical phase under the influence of Schopenhauer and Wagner, (ii) an anti-metaphysical positivist phase, and (iii) a phase in which he is concerned with the development of an approach to values within positivist strictures. Schlick is careful to argue that the third phase in Nietzsche's development is still compatible with positivism, and that the late Nietzsche is not a metaphysician. Thus, for example, Schlick (2013a, pp. 293-294) interprets Nietzsche's view of eternal recurrence as scientific, and not metaphysical.

Intriguingly, Schlick's 1912-1923 lectures overlap with a time in his intellectual development in which he upheld what has been characterized as critical or structural realism, and not positivism. In fact, during this time, Schlick was critical of specific types of positivism, and had raised a series of objections against the Machian positivist (or 'empiriocriticist') view of science (see Lewis 1988, Textor 2018). His portrayal of Nietzsche as a positivist does not, however, diminish the degree of influence he had on Schlick's early realist phase. In fact, as we shall see in the discussion of Schlick's conception of Wissenschaft in Section XY.8, Schlick explicitly appeals to Nietzsche and his notion of a ‘joyful science’ in opposing Mach’s and Avenarius's explanations of scientific knowledge in

\footnotetext{
${ }^{21}$ A tension may be here detected between Schlick's intertwining of Nietzsche's life and thought on the one hand, and on the other hand his views concerning the autonomy of the search for truth from practical concerns (which I examine in section XY.9). If the search for truth is truly autonomous from practical concerns, in the way Schlick describes, then why should an account of Nietzsche's life be relevant to his philosophical ideas? Schlick's lectures are clearly not only concerned with Nietzsche's writing styles and ideas, but also with accounting for their genesis. Nietzsche's life is interesting in connection with the latter purpose, and Schlick uses it to helps his audience better understand the context in which Nietzsche's style and ideas developed, as well as to clarify some of his intentions. Nonetheless, though Schlick does not state this in the Nietzsche lectures, he would probably agree that the genetic account has little to do with the assignment of truth-values to Nietzsche's propositions.
} 
terms of a drive to pleasure (see also Mormann 2010, pp. 268-269; Ferrari 2016, p. 9; Textor 2018, pp. 114-115). In other words, Schlick's early critique of positivism focuses precisely on the Machian conception of knowledge, from which he seems to exempt Nietzsche, whom he interprets primarily as an ally to his view.

Schlick's early realist phase ended with his conversion to positivism in 1922, which would bring him even closer to Nietzsche as he portrays him in his lectures. Though Schlick does not directly address this, other Vienna Circle members follow Schlick in portraying Nietzsche as a predecessor of the positivist overcoming of metaphysics. Whether directly through Schlick's influence or not, Frank ([1917] 1970, pp. 232-234), ${ }^{22}$ Neurath ([1921] 1973, p. 196; [1936] 1981, pp. 692, 687; [1938] 1955, pp. 10-11, 18; [1932] 1987, pp. 10-11; [1938] 1981, p. 826), and even Carnap ([1928] 2003, pp. 105, 108-109, 271; [1931] 1959a, p. 80; [1932] 1959b, pp. 167-168) will, in various passages, interpret Nietzsche as a positivist critic of metaphysics, and thus as a predecessor of the Circle. ${ }^{23}$

The above summary illustrates what is at stake in Schlick's 1914 defense of Nietzsche. Schlick is concerned with much more than simply a disinterested dispelling of misinterpretations of some random figure in the History of Philosophy. Schlick's motivation for criticizing the militaristic reading of Nietzsche is, to some extent, politically motivated, insofar as he seeks to answer the British propagandists' claims. But Schlick is also motivated philosophically, insofar as he wants to defend the reputation not only of a writer who had urged his teenage self to take up philosophy, but also of an ally in upholding a Wissenschaftliche conception of philosophy. A further, connected, motivating factor is the

\footnotetext{
${ }^{22}$ See also Von Mises ([1938] 1987, pp. 169, 171).

${ }^{23}$ See also Fischer (1982); Tuusvuori (2000, pp. 159-162, 233, 290-292, 678-680); Mormann (2015). A possible objection about this claim might be raised concerning its compatibility with what Carnap ([1931] 1959a) states about Nietzsche, given that he explicitly classifies him as 'the metaphysician who perhaps had artistic talent to the highest degree' (p. 80). In what may appear at first glance confusing, Carnap goes on to argue that Nietzsche divided his work into empirical studies, on the one hand, and on the other hand poetry, through which 'he expresses most strongly that which others express through metaphysics' (p. 80). In other words, Carnap at first classifies Nietzsche as a metaphysician, and then proceeds to say that he avoided metaphysics, expressing his Lebensgefühl through artistic means. Is Carnap claiming that Nietzsche is a metaphysician who avoids doing metaphysics? One possible way of resolving the tension here would be to see Carnap as endorsing the tripartite understanding of Nietzsche's work that Schlick also presented in his Rostock lectures. According to this interpretation, Nietzsche was initially a metaphysician, and then came to overcome his metaphysical inclinations, becoming instead a positivist. Carnap can thus be understood to claim that Nietzsche, who was once a representative of Schopenhauerian metaphysics, abandoned its errors and confusions, becoming instead a positivist by focusing his work on either empirical studies or poetry. Interpreting Carnap thus allows us to align his position with that upheld the rest of the Circle's members, except for Waismann.

By contrast to his Vienna Circle colleagues, Waismann (1994a and 1994b) wrote critically about Nietzschean ethics. Furthermore, perhaps unaware of his teacher's views on the matter, Feigl would later join other Anglophone analytic philosophers in talking of "such views as those of Nietzsche, Hitler, and Mussolini on the 'greatness' of war" ([1952] 1981, p. 383).
} 
urge to clarify the proper relation between philosophy and war, on the one hand, and to politics more broadly on the other.

\section{XY.5. Schlick's Defense of Nietzsche}

As already established above, Schlick had written his lecture notes on Nietzsche in 1912. The lecture course was not offered in 1913, and, as Iven (2013b, pp. 67-68) notes, Schlick had prepared to lecture on the topic again during the winter semester of 1914/1915. It is unclear, as already mentioned, whether the plan had to be aborted due to the outbreak of the war. ${ }^{24}$

In October 1914, Schlick wrote a special introduction to his lectures which would address a topic that was publicly debated at the time, namely the relation between Nietzsche's ideas and the outbreak of the war. At a time, as we have seen, when most of Schlick's colleagues were seeking for ways in which philosophy could contribute to the war effort, the main impetus for Schlick's response to both controversies is that of calling for moderation and opposing the contemporary militaristic frenzy. ${ }^{25}$ As we have seen, Schlick wrote at a time when attention was shifting away from the Nietzsche controversy, and towards the nascent controversy about German Idealism. ${ }^{26}$ Thus, though his primary concern was with Nietzsche, Schlick was well placed to respond to both controversies. In fact, as we shall see, Schlick will set one controversy against the other, showing that one cannot, without contradiction, blame the war both on Nietzsche and on the Idealism which he opposed.

In the introduction to his lectures, Schlick objected not only to the use of Nietzsche's work as a justification for militarism, but also to any urge to seek justifications for militarism in philosophy. Schlick proposes a psychological hypothesis to explain this type of urge. War, according to Schlick (2013a, p. 77), is so overwhelming that it can bring about certain cognitive and affective distortions and biases. Schlick thinks that the association of ideas can explain such biases, and claims that through repetition, the idea of war comes gradually to be

\footnotetext{
${ }^{24}$ The lectures were paused again in 1917-1918. Upon resuming the lectures in 1919 up to 1923, Schlick added a preliminary section on Schopenhauer, whose thought he presented by way of an introduction to Nietzsche. See Schlick (2013a, pp. 34-35).

${ }^{25}$ See also Wolters (2017; Forthcoming).

${ }^{26}$ Schlick's position can be opposed to one of the few subsequent Germanophone academic responses to the Nietzsche controversy, namely that by the sociologist Werner Sombart. By contrast to Schlick, Sombart (1915, p. 53) conceded the propagandists' claim that this is indeed 'Nietzsche's war', only to qualify this in a manner which connects to his overall conception of the war as a battle between German Culture and the Entente powers' mere Civilisations. (Coincidentally, Schlick also rejects contemporary caricatures of English civilization's reliance on a type of mercantile utilitarianism, which later find their way into Sombart's work; see Vrahimis 2015, pp. 89-90; Wolters 2017, p. 14).
} 
associated with almost every thought and feeling in every realm of human activity. ${ }^{27}$ As a result of association, there emerges a kind of involuntary drive or "inner compulsion" (Schlick 2013a, p. 78) towards connecting all facets of life to the war. Schlick thinks his hypothesis explains why even his contemporary philosophers are obsessed with the war. In Schlick's account, the desire to embroil philosophy in debates about the war is diagnosable as a symptom of the overwhelming nature of war as he has outlined it. War seeks to infiltrate all human "life, feeling, and thought" (Schlick 2013a, pp. 77), even in philosophy which is the most abstract form of thought.

Schlick concedes that his own entry into the debate concerning philosophy's relation to the war is also explained by his psychological hypothesis. In other words, like his opponents, he is also subject to the same law of association which makes connections between war and all kinds of other phenomena. Schlick acknowledges that his hypothesis does not necessarily amount to an argument against debating the relation between philosophy and war, or other such overwhelming contemporary events. Thus his hypothesis does not bar him from entry into the debate. Entering the debate, Schlick will argue for the dissociation between war and philosophy. In fact, as we shall see in Section XY.9, Schlick's claim is based on the view that philosophy, qua Wissenschaft, presupposes an ability to stand back from all drives associated with practical pursuits (among which we can include the involuntary drive to connect everything with war).

Schlick further seems to imply that his hypothesis concerning the all-encompassing nature of war could account for the types of aggression that were involved in the disputes of his contemporary philosophers and journalists. The aim on each side is to claim for itself the 'correct' philosophical legacy, while blaming its opponents' participation of the war on their choice of the wrong philosophical legacy. If it is true, as Schlick will show, that the very notion of a philosophical justification for war is absurd, then it also follows that the attribution of blame for war to some philosophical tradition or other is misguided.

Having presented his psychological hypothesis, Schlick proceeds to examine specific examples which draw this connection. His main focus is the aforementioned British propaganda and its connection to the Nietzsche controversy. In Schlick's account, the propagandists make extravagant claims about the role of power in German Realpolitik. Schlick summarizes the British press' depiction as follows:

\footnotetext{
${ }^{27}$ On the role associationist psychology plays in the early Schlick's response to Mach, Avenarius, and Schopenhauer, see Textor (2018, pp. 111-112, 116, 119).
} 
Power, brutal power, was proclaimed to be the highest ideal by us, our spiritual leaders openly stand in opposition to morality, a new master morality [Herrenmoral] was preached by us (viz. a morality of authoritarian strongmen, by contrast to a Christian morality of humility); we were striving for a revaluation of all values, we wanted to impose the new anti-moral values on Europe and the whole world. (Schlick 2013a, 79)

Schlick goes on to note that the propagandists depict Nietzsche as the mastermind behind this type of mentality, with newspaper headlines using slogans like "Germany at Nietzsche's feet" (Schlick 2013a, p. 79). ${ }^{28}$

Schlick's notes do not go into further detail about the nature of the link that British propagandists had drawn between Nietzsche and German politics. This may partly be explained by the fact that the journalists' polemical exaggerations did not really offer much by way of argument for their position. As we have seen above, it was simply asserted that Nietzsche was an amoral atheist whose power-hungry vision had served to shape German politics. However, it is also likely that Schlick could expect from his audience in 1914 to have been familiar with the relevant accusations, and so he does not need to repeat them at great length. Thus after his brief summary, Schlick immediately leaps to a defense of Nietzsche.

Schlick's first response is to note that to anyone familiar with Nietzsche's life and work - as his students will (ideally) be by the end of his course - such accusations will appear strange, and their couching in Nietzschean vocabulary (using terms such as 'power' or 'revaluation of all values') is misleading. Schlick's defense of Nietzsche focuses on two points, which the propagandists confusedly combine. On the one hand, the propagandists miscalculated Nietzsche's influence on German culture and politics. On the other hand, they misunderstood Nietzsche's work.

Schlick summarily rejects the claim that Nietzsche's thought had heavily influenced the development of German culture and politics before 1914. It suffices for Schlick (2013a, p. 79) to note that few political or military leaders in Germany had even heard of Nietzsche before the British press informed them of his influence on them. Even if some German policy-makers did hear of Nietzsche, they were by no means enthusiastic about his work. ${ }^{29}$

\footnotetext{
${ }^{28}$ Schlick does not cite a specific source for this quote, and I have been unable to find a specific mention of this phrase in a contemporary newspaper. It is most likely that Schlick here is simply mimicking the exaggeratedly polemical tone of the popular press (in a manner that is relatively mild by comparison to the claims about Nietzsche's diabolical status that we examined above).

${ }^{29}$ But see e.g. Thomas' (1983) overview, which demonstrates that Nietzsche had an significant influence on German politics, including Socialism, Anarchism, Feminism, the Youth Movement to which various Vienna Circle members were connected, and also Social Darwinist tendencies. Whether this implies Schlick was wrong
} 
Furthermore, Schlick connects this first claim to the second one, insofar as he doubts that Nietzsche's work has been widely understood in Germany.

Here, Schlick seems to have missed an opportunity to more adequately address the specific claim at stake in the controversy, i.e. Nietzsche's purported influence on state policy through Treitschke and Bernhardi. In fact, in his original sketch for his lecture notes, Schlick (quoted in Iven 2013b, p. 68) noted down both these names, but seems to have later given up the effort to directly address the topic in any more detail. It would have been easy to show (as, for example, we have seen Stewart did later on) that the journalistic claim concerning Treitschke and Bernhardi commits both mistakes that Schlick detects in the Nietzsche controversy. On the one hand, Schlick could question whether there is any evidence that either Treitschke or Bernhardi had a significant influence on the events of the First World War. On the other hand, Schlick could argue that the militaristic reading of Nietzsche that the journalistic controversy attributed to Treitschke and Bernhardi was a mistake, due to an overall misunderstanding of his philosophy.

Schlick thinks that even if the caricature of Nietzsche as an anti-moral, power-hungry philosopher were to be accepted, this could not entail that

the Germans [...] thereby could have become wild beasts that attack their neighboring peoples so as to satisfy their own will to power, at the expense of all moral feelings. (Schlick 2013a, p. 80)

It would, in other words, take a few further steps to show that, even if the militaristic interpretation of Nietzsche (whether mistaken or not) was widely accepted in Germany, this did in fact result in the kinds of amoral actions attributed by the British propagandists to the German state.

It should be noted that a degree of vagueness surrounds the second of Schlick's claims, i.e. that the propagandists misunderstood Nietzsche. Schlick seems to promise that he will offer a more robust philosophical defense of this claim, and hopes to convince his students that his interpretation of Nietzsche clears him of the accusation that he is a militarist. Sadly, Schlick does not specify in which way the subsequent lectures correct the propagandists' misunderstandings of Nietzsche, and simply notes that it will be made clear to his audience that they are.

to note that Nietzsche did not influence state policy depends on determining the extent to which these tendencies had such an effect, and the degree to which such an effect connected to their influence by Nietzsche; these are historical matters that I cannot resolve here. 
At first glance, it should be noted that Schlick's interpretation of Nietzsche is quite controversial. As already noted, in Schlick's lectures he interpreted Nietzsche as becoming, after his early metaphysical Schopenhauerian phase, a positivist. Insofar as he holds that this is the correct interpretation of Nietzsche, he would be justified to assert that almost all of his interpreters at the time had fundamentally misunderstood him. ${ }^{30}$ If this is to be the basis of Schlick's claim that Nietzsche is not a militarist, then it may not be very convincing to anyone who resists the view that he was a positivist.

There are two ways in which Schlick does explicitly substantiate his claim that Nietzsche cannot be correctly interpreted as a militarist. Both are much more specific than the vague contention found in his introduction to the Nietzsche lectures. It should be remembered that the 1914 text consists merely of lecture notes, a fact which may explain their incompleteness - so perhaps it would be justifiable to look elsewhere for a more extended account. The first of Schlick's explicit defenses of the claim that Nietzsche was not a militarist is developed, within a different context, in Natur und Kultur, which I examine in Section XY.6. A second defense of his claim, to which I will return in Section XY.7, relates to an inconsistency between the Nietzsche controversy and the German Idealism controversy, since, as Schlick detects, they involve incompatible claims.

There is a further way in which Nietzsche's influence on Schlick connects to his separation between philosophy and militarism. In the early Schlick, this is a result of his conception of philosophy as the pursuit of truth. Schlick pits this metaphilosophical view against the possibility of any involvement of philosophy in militaristic discourse. Schlick's early metaphilosophy, as I will endeavor to show in Section XY.8, is an outgrowth of his interpretation of Nietzsche (as already intimated by my account of Schlick's influence by Nietzsche in Section XY.4). The relevant separation between philosophy and politics also continues, as I will show, in Schlick's later view of philosophy as the pursuit of meaning.

\section{XY.6. Schlick's Rejection of the Interwar Far-right's Interpretation of Nietzsche}

Schlick's return to the question of Nietzsche's connection to militarism in Natur und Kultur is no longer a response to the British propagandists of 1914, but rather primarily an answer to the far right's attempt to appropriate of Nietzsche's during the interwar period. Schlick's brief commentary on Nietzsche in this unfinished book from the 1930s is presented within a

\footnotetext{
${ }^{30}$ A significant exception was Kleinpeter's (1913) book (published later than Schlick's 1912 lectures), in which he argued that Nietzsche's epistemology is comparable to Mach's.
} 
broader context of criticizing authoritarian conceptions of the state. ${ }^{31}$ Schlick mentions the "prophets" (1952, p. 77) who misinterpret Nietzsche as endorsing a kind of supra-moral status for states. According to such misinterpretations, which are almost identical to those presented in the journalistic controversy of 1914, Nietzsche's critique of Christian morality applies to states, and entails that they may exercise their power without restraint, for example by waging war through any means possible.

Schlick acknowledges that it is easy to misunderstand Nietzsche in this militaristic manner, given that his writings do in fact appear to glorify war. However, as Schlick points out, like anyone who had not witnessed the First World War, Nietzsche could not possibly conceive of modern technological warfare. Though traumatizing, Nietzsche's experience during the Franco-Prussian war, which Schlick details in his 1912 lectures (2013a, pp. 151154), was far removed from the horrors of trench warfare:

\footnotetext{
The word 'war' has, today and in politics, a very different reference than it had in Nietzsche's mouth: it refers today to a horrible, nationwide organization of annihilation, by which all sorts of machines hurl, from as far away as possible, exploding masses of steel and poisonous gases [...] it is an indiscriminating rampage of the will to destroy; not a competition, not a selection, but a natural catastrophe, a mass phenomenon [Massenerscheinung] - all quite incompatible with that which Nietzsche understands as war. (Schlick 1952, pp. 77-78)
}

Schlick does not think that Nietzsche would have any praise for such technologically induced horrors, and the herd mentality that underlies them.

Nietzsche does not, in Schlick's account, condone unrestricted technological warfare between states, i.e. herds fighting herds. Instead, according to Schlick's individualist interpretation, Nietzsche's praise of war should be better understood as praise for altogether different types of warfare. The main examples Nietzsche has in mind, according to Schlick, are the kinds of warfare that take place among individuals within society, or of "the struggle of the individual against the masses" which "it would be ridiculous to imagine as a battle with riffles and rapid-fire guns" (Schlick 1952, p. 77). What best instantiates, according to Schlick, the kind of warfare that is a prerequisite for the Nietzschean Übermensch is humanity's struggle against nature (notably also William James' proposal of “an army enlisted against Nature" (1911, p. 290) that should come to replace wars among humans). As evidence for this, Schlick cites part of a relevant passage from Nietzsche's plan for the third book of his

\footnotetext{
${ }^{31}$ Schlick also includes a criticism of Hitler in the same chapter (1952, p. 86). For an analysis of Schlick's account of the state, see Schleichert (2003).
} 
unfinished The Will to Power, where he sketches his conception of the will to power as follows:

The will to power.

How the men undertaking this revaluation of themselves would have to be constituted.

The order of rank as an order of power: war and danger required for a rank to maintain its conditions. The grandiose prototype: man in nature; the weakest, cleverest being making itself master, subjugating the more stupid forces. (Nietzsche 2003, p. 87).

In this passage, while Nietzsche seems to take war to be unavoidable, he does indeed designate the type of war that he has in mind as that between humanity and nature. The broader context for this is Nietzsche's aristocratic conception of a master-morality. Though Schlick notes that he disagrees with this idea, he states that a complete attempt to refute it cannot be undertaken within the context of his discussion of the state. ${ }^{32}$ Against Nietzsche's aristocratic critique, he mentions that a morality of kindness [die Moral der Güte] is not in any way exclusive to Christianity, or to any "individual peoples or states" (Schlick 1952, p. 78), but exists throughout all human cultures.

Contrary to a lot of subsequent scholarship that had focused on this element in Nietzsche, Schlick rejects the idea that his conception of power and its relation to morality, which Schlick thinks to be highly problematic, is a central part of Nietzsche's work. Instead, Schlick presents such elements in Nietzsche (which would perhaps undermine his own account) as the weakest, and most misguided, aspect of his overall worldview. Schlick closes his commentary on Nietzsche as follows:

\footnotetext{
I hold him to be the richest, most ardent mind of the nineteenth century, but concerning the nature of power I seek from him no guidance, just as I would not concerning a mathematical question. It is the bitterest fate for a Great man, when he works more through his falsehoods than through his truths. (Schlick 1952, pp. 78-79)
}

Schlick's contention about Nietzsche's falsehoods in the context of Natur und Kultur is a direct attack against the claim to Nietzsche's legacy made by his contemporary far-right. Contrary to many of their Anglophone analytic colleagues, many of whom would have been directly or indirectly aware only of the British side in the Nietzsche controversy, ${ }^{33}$ Schlick

\footnotetext{
${ }^{32}$ Waismann (1994a, and 1994b) would later undertake a more extensive critique of Nietzsche's ethics.

${ }^{33}$ See Akehurst (2010, e.g. pp. 18-25, 55-58, 69-70, 96, 101-104).
} 
and other Vienna Circle members resisted the far-right appropriation of Nietzsche. In Schlick's view, there may have been elements in Nietzsche, at his worst, that could be misunderstood and put to political use by militarists and fascists. ${ }^{34}$ However, at his best, Nietzsche was a positivist predecessor of the overcoming of metaphysics, a project that was later to be undertaken by Logical Empiricism.

\section{XY.7. 'Beautiful nonsense': Schlick on German Idealism}

As mentioned above, in 1914 Schlick has a further reason for rejecting the blame put on

Nietzsche's work as a cause for German militarism. This concerns what he sees as a contradiction between the two prominent views in the two controversies during the war, one about Nietzsche, the other about German Idealism. What is debated in the former is whether Nietzsche's thought is purportedly responsible for German militarism. What is at stake in the latter is the relation between German wartime aggression and German Idealism, in a line of influence that goes back to Kant. In response to the two controversies, Schlick notes that Nietzsche's and Kant's views in normative ethics are polar opposites. Kant conceives of morality as pertaining to duty, and not to natural inclination. ${ }^{35}$ Nietzsche holds the reverse view, and according to Schlick, Nietzsche and Kant are "antipodes" (2013a, p. 80). ${ }^{36}$ Thus, Schlick argues, the propagandists will have to choose: do they believe that the war was caused by too strict a Kantian adherence to moral duty, or by Nietzsche's devilish undermining of all moral standards?

Schlick rejects both claims: neither Nietzsche nor the German Idealists, qua philosophers, are responsible for the war. In rejecting the latter claim, Schlick offers a historical argument concerning the origins of the association between German Idealism and

\footnotetext{
${ }^{34}$ An interesting parallel case to be noted here is that of Neurath's and Lauwerys' (1944a, 1944b, 1945) contention that Plato's Republic should be banned from being taught in Germany after the Second World War. Their main argument was that Plato's work presents some of the basic racist and militaristic ideas that were deployed by the Nazis, and so their adherents could go on preaching such ideas after the war, referring to Plato instead of Hitler; see also Soulez (2019), Tuboly (2020b). Interestingly, Nietzsche's name only makes a brief appearance in their polemic against Plato - he is not mentioned as an inspiration for the far right, but merely admonished for his admiration for Frederick II (Neurath and Lauwerys 1944b, p. 575). In other words, Neurath and Lauwerys resist the urge to blame Nietzsche for the rise of Nazism (as would many others in the aftermath of the Plato controversy).

Interestingly, Schlick's defence of Nietzsche and Neurath's and Lauwerys' indictment of Plato, though parallel in many ways, move in opposite directions. Schlick pronounces Nietzsche's innocence by attempting to dispel any possible militaristic interpretations of Nietzsche as misguided. By contrast, Neurath and Lauwerys indict Plato by warning against the danger of a possible racist and militarist interpretation of the Republic.

${ }^{35}$ Kantian morality was among Schlick's targets already in Lebensweisheit, and would continue to be so in later work; see Ferrari (2016).

${ }^{36}$ Neurath ([1938] 1955, p. 11) would also later present Nietzsche as a predecessor to Logical Empiricism in part due to his critique of Kant.
} 
German nationalism. According to Schlick (2013a, p. 81), such an association was common in the early nineteenth century, when philosophers in the Idealist tradition, most notably Fichte, happened also to present their defenses of nationalist ideas in the public sphere. Interestingly, Schlick addresses the case of Fichte by arguing for a separation between his philosophical and his political ideas. He states that the popular appeal of the latter is primarily due to Fichte's "admirable moral character and personality" (Schlick 2013a, p. 81), and has little to do with his highly problematic philosophical outlook. A strict line must be drawn, in Schlick's account, between Fichte's work as a political orator and his philosophical ideas. For Schlick, Fichte's political works are explicitly not philosophy. ${ }^{37}$

In his 1914 lecture notes, it becomes clear that Schlick does not think very highly of the philosophical works of the German Idealists. He claims, for example, that the Idealists' promises of 'Wissenschaft' (e.g. in the title of Fichte's Wissenschaftslehre) are deceitful. Instead, their work often contains statements that fly in the face of scientific fact. Schlick gives the example of Hegel's denial, two centuries after Galileo, that the stars are celestial bodies, in preference to the view that they are "only abstract points of light" (Hegel 2004, p. 297). Contrary to those who would see them as the epitome of German thought, Schlick argues that their work constitutes a "most lamentable regression" (2013a, p. 82) in the history of philosophy. By contrast, he considers the preceding phase in the history of German philosophy, namely the late eighteenth century, to have been "a true heyday" (2013a, p. 82 original emphasis). The systems of Fichte, Hegel, and Schelling fail to live up to the rigorous standards of their predecessors:

in place of the strict discipline of thought that we find in Kant, we find in Fichte, Schelling [and] Hegel airy speculation, leading to a momentary dazzling, but not to lasting truth. (2013a, p. 82)

As Schlick clarifies, his rejection of the idealist systems relies on a conception of philosophy as the pursuit of truth, which he designates as the primary task of philosophy (2013a, p. 81). Notably, though he thinks they don't live up to the task, Schlick would later explicitly attribute a version of this conception of philosophical methodology to Hegel and Schelling. According to Schlick, they conceive of philosophy as a special kind of path to truth:

\footnotetext{
${ }^{37}$ Schlick's account seems to presuppose that Fichte's political works are generally misunderstood to be works of philosophy, a view which he is contesting. More problematically, Schlick does not address the fact that, however one categorises them, Fichte's political oratory draws its authority from the status of its author as a canonical Great Philosopher.
} 
In Germany at the beginning of the nineteenth century Schelling, Fichte, and Hegel believed that there was some kind of royal path leading to truth which was reserved for the philosopher, whereas the scientist walked the pathway of the vulgar and very tedious experimental method, which required so much merely mechanical technique. They thought that they could attain the same truth that the scientist was trying to find but could discover it in a much easier way by taking a short cut that was reserved for the very highest minds, only for the philosophical genius. (Schlick [1932] 2008a, pp. 376-377)

The early Schlick was in agreement with the Idealists, insofar as they both conceived of philosophy as a pursuit of truth. As I will discuss in detail in what follows, he would subsequently come to reject this metaphilosophical thesis, replacing it with a conception of philosophy as the pursuit of meaning. It is, in fact, in this context that the passage quoted above was written, as part of Schlick's critique of the conception of philosophy as a pursuit of meaning. Under both conceptions of philosophy, however, Schlick thinks Fichte, Schelling, and Hegel fare pretty badly for the same reasons, namely due to their ignorance of scientific facts.

According to Schlick in 1914, it follows that the Idealists miss the mark by the standards set both by his and by their own conceptions of philosophy as the pursuit of truth. In Schlick's view, deprived of any value as Wissenschaft (i.e. as the pursuit of truth), the Idealists' work consists primarily of emotional expressions. This culminates in Schlick's conclusion, in reference to Fichte, Hegel, and Schelling, that

\footnotetext{
If one understands philosophy as nothing more than belletristic talk about things, as throwing around provocative thoughts and as reveling in high feelings unrelated to reality, then possibly these structures of thought have their legitimacy. (Schlick 2013a, p. 81)
}

It is notable that we find here, already in this underdeveloped form from 1914, a line of thought that will come to play a central role in subsequent criticisms weighed by the Vienna Circle against metaphysical thinkers. Schlick will repeat some very similar claims about the Idealists in later works, such as his 1931 draft of "Philosophy as the Pursuit of Meaning":

We know what happened when, in the days of Schelling and Hegel, philosophy undertook to bridge the gulf then existing between the various branches of science before patient experimental research had reached the general principles which made such an undertaking possible: the philosophers furnished principles of their own, which they believed to be the expression of some deep insight into the nature of things, but which in reality were even less than hasty 
generalisations of superficial truths. They were nothing but vague metaphors of no cognitional value.

The result of such a "philosophy" was at best some beautiful nonsense. (Schlick 2013b, pp. 129-130).

Notice that Schlick here uses almost the same vocabulary as found in the Nietzsche lectures, e.g. in his reference to the primarily aesthetic appeal of the Idealists' writings. Like the Nietzsche lectures, Schlick's 1931 article goes on to list various false scientific theories upheld by the idealists (2013b, p. 130). These now include not only Schelling's and Hegel's misunderstandings of electricity, but also the same basic misunderstandings of astronomy that we find in Hegel, which Schlick in 1931, perhaps slightly more charitably, further explains as Hegel's attempt to connect astronomy with optics. ${ }^{38}$

There are, however, two important differences between Schlick's verdicts in 1914 and 1931. Firstly, as already noted, in 1931 Schlick is explicitly rejecting the notion that philosophy is in any way engaged in the pursuit of truth. Having moved away from his early realist phase, Schlick would deny that philosophy is identical with Wissenschaft. As we have seen, he even cites Hegel and Schelling in rejecting the idea that philosophy is a kind of path to truth that is nobler than science. Instead, as we shall see in more detail soon, Schlick argues that philosophy is an activity of clarifying meaning. The shift towards a conception of philosophy as the pursuit of meaning accounts for a second noticeable difference between the 1914 and 1931 texts, namely the addition in 1931 of the term 'nonsense' to the charges laid against the Idealist system-builders. This signifies its connection to verificationism, which underlies Schlick's understanding of the pursuit of meaning.

Despite these differences, the overall polemical attitude displayed by Schlick towards the Idealists remains, as we have seen, at its core unchanged between 1914 and 1931. Like later anti-metaphysical work by the Vienna Circle, Schlick's 1914 lecture criticizes the Idealists for preferring aesthetically beautiful poetic modes of emotional expression over the philosophical pursuit for truth. ${ }^{39}$ We can find the same attitude in Neurath's 1921 accusation of Spengler as a pseudo-rationalist, by which he means a poet or a prophet disguised as a philosopher ([1921] 1973, 160; cf. Vrahimis, 2020b). We can also see an analogous attitude in Carnap's 1931 contention that metaphysicians (e.g. Heidegger) are like failed poets or

\footnotetext{
${ }^{38}$ In his draft for the article, Schlick (2013a, p. 141) explicitly cites Hegel's account of the stars as abstract points of light, and also names Hegel's theory of heat (which he does not further explore, but only cites the relevant passage).

${ }^{39}$ Bertrand Russell had weighed similar accusations against Bergson in 1912; see Vrahimis (2011, 2019, 2020c).
} 
'musicians without musical ability' ([1931] 1959a, p. 80), while Nietzsche's overcoming of metaphysics implied that he divided his work between undisguised poetry (e.g. in Zarathustra) on the one hand, and purely empirical studies on the other (see Vrahimis 2013, pp. 31-86).

\section{XY.8. The Game of Value-free Wissenschaft}

A further notable aspect of the 1914 passage by Schlick is that it prefigures his subsequent apolitical rejection of metaphysics (whereby Wissenschaft is strictly separated from any political stance), and by extension his disagreement with the 'left' Vienna Circle's conception of the political role to be played by the overcoming of metaphysics. As already noted above, Schlick's 1914 criticism of the Idealist blurring of philosophy and emotional expression is based on his conception of a purely theoretical search for truth. But what exactly was it that Schlick had in mind in 1914 when he identified philosophy with a search for truth?

In order to determine this, one must look to Schlick's evolutionary account of the value of knowledge, an account that will remain central throughout his work (see e.g. Mormann 2010, p. 267; Ferrari 2016). In his earliest writings, this is expressed as the view that Wissenschaft is the product of a "will to truth" (Schlick [1908] 2006, p. 86; see Ferrari 2016; Textor 2018, pp. 117-118). This view, as already mentioned, is the result Schlick's reworking of Nietzsche's 'will to power' (see e.g. Iven 2013b, p. 58; Ferrari 2016, p. 7). In Lebensweisheit, Schlick ([1908] 2006, 170-181) chooses to present it under a motto from Nietzsche's Zarathustra: "Then, however, was Life dearer unto me than all my Wisdom had ever been" (Nietzsche [1885] 1905, 232). A central element in Schlick's evolutionary account of Wissenschaft is a distinction he draws between two possible attitudes that can be taken towards objects in the world (Schlick [1908] 2006, p. 86): a theoretical one, which concerns facts (or in Schlick's terminology, the nature ("Wesen" ([1908] 2006, p. 86)) of objects), and a practical one concerned with values. According to Schlick, all practical evaluations are guided by a fundamental drive that he calls the "will to pleasure". Lebensweisheit is primarily concerned with working out the consequences of this conception of values within a broad evolutionary framework, in which the will to pleasure guides the interests of all living things, from animals to humans. Within this framework, Schlick is faced with the problem of explaining how it is possible that a theoretical attitude can arise at all. In other words, Schlick asks: how is it possible that the human animal, primarily concerned with its survival and driven by its will to pleasure, may develop a 'will to truth', a pursuit of knowledge for the sake of knowledge rather than for some specific other practical end? 
Schlick's 1908 conception of the evolutionary emergence of Wissenschaft in the human animal can be broken down into four elements:

1) Pure will to pleasure: in this first stage, qua animal, the human being is guided in its activities purely by considerations concerning the fulfillment of some practical end, through the 'will to pleasure'. Everything in this stage is seen "from the point of view of value" (Schlick [1908] 2006, p. 170).

2) Technological thinking: in this intermediary stage, we have a kind of technological thinking guided by practical ends, namely an attempt to make predictions based on past experiences. According to Schlick, the human brain evolved so as to be able to associate past experiences with conclusions, which in turn can be used as predictions for future actions, and is thus conducive to the human animal's survival.

3) (Purposeless) games: In another intermediary stage, Schlick proposes that we imagine a human animal that, for whatever reason, has temporarily had all other drives satiated. Out of curiosity, the human can come to pose some question or puzzle that is irrelevant to its practical interests. It can pursue such a puzzle in the form of a game, i.e. an activity primarily undertaken for its own sake, and which, after a process of habituation, can even become pleasurable without being guided by practical interests. ${ }^{40}$

4) Games guided by the 'will to truth': The fourth stage is a combination of the basic elements of the previous two stages. Guided by practical concerns, humans find that posing questions about predictions works better when set in the context of a game, rather than when pursued for this or that specific practical end. This, in Schlick's account, explains the development of the 'will to truth', and thus of Wissenschaft. On the one hand the search for truth is undertaken for its own sake, while on the other hand it is instrumental in predicting future events, and thus conducive to survival. By contrast to one intermediary stage (2), it is guided by theoretical, not specific practical interests. By contrast to another intermediary stage (3), which may involve any playful stream of thought, Wissenschaft is limited insofar as it is determined by the 'will to truth'.

Schlick thinks of Wissenschaft as, ideally, a kind of game, in so far as it is an activity primarily undertaken for its own sake, and which can be pleasurable without being guided by

\footnotetext{
${ }^{40}$ Schlick designates this moment as the birth of Wissenschaft ([1908] 2006, p. 171).
} 
practical interests (see also Mormann 2010, pp. 269-272). This is how Schlick interprets Nietzsche's notion of "joyful wisdom", the joy involved in the game of pursuing truth. He opposes this to the pursuit of knowledge as work, i.e. directed towards specific practical goals other than itself. In fact, Schlick takes a very critical stance towards the idea of Wissenschaft undertaken as a kind of job, named "research" ([1908] 2006, p. 180), whose sole aim is academic advancement (or 'fame and glory' ([1908] 2006, p. 180)), and which is associated with a certain seriousness and gravity. Instead, Schlick waxes lyrically about

[t]he sensitive Nietzsche, who felt this disharmony perhaps especially in himself, therefore praises, in contrast to this unhappy practice of erudition, the 'joyful Wissenschaft' of the wise.

Wise is he $[s i c]$ to whom the contemplation of the world and the search for truth have bestowed all their blessings [...] which the Play of the Spirit effuses on all who give themselves to it (Schlick, [1908] 2006, p. 181)

Schlick recruits Nietzsche as a proponent of his notion of Wissenschaft as 'joyful', in that it involves a pleasurable game of pursuing truth.

Like the technological thinking that gave rise to it, Wissenschaft does of course serve practical purposes, insofar as it makes successful predictions. Nonetheless it is of crucial importance for the production of successful predictions that truth itself, and no other end, is what is pursued! Successful predictions presuppose the ability to take a purely theoretical attitude, which aspires only to truth and is thus divorced from practical evaluations. As Schlick puts it,

[e]ven if science does not draw its conclusions for the purpose of action, the truth of its propositions can of course (this follows from the above definition of truth) only be tested by the success of actions; the latter are then called experiments. (Schlick, [1908] 2006, p. 173)

Schlick returns to this theme in later work, most strikingly perhaps in the midst of his contribution to the Protocol-Sentence debate, ${ }^{41}$ in his 1934 "The Foundation of Knowledge". There we find Schlick making the following claim:

Cognition is originally a means in the service of life. In order to find his way about in his environment and to adjust his actions to events, man must be able to foresee these events to a certain extent. For this he makes use of universal statements, cognitions, and he can make use of

\footnotetext{
${ }^{41}$ For the classic discussion of the debate and its significance for the development of Logical Empiricism, see Uebel (2007); see also Uebel (2020).
} 
them only in so far as what has been predicted actually occurs. Now in science this character of cognition remains wholly unaltered; the only difference is that it no longer serves the purposes of life, is not sought because of its utility. With the confirmation of prediction the scientific goal is achieved: the joy in cognition is the joy of verification, the triumphant feeling of having guessed correctly. And it is this that the observation statements bring about. (Schlick [1934] 1959, pp. 222-223)

Though the addition of Schlick's conception of Konstatierungen is a new, perhaps more technical, element here, the view of Wissenschaft developed in Lebensweisheit is clearly repeated in the above passage more or less unaltered. ${ }^{42}$ The same approach to the value of knowledge, i.e. in terms of a drive to pleasure which is explained in evolutionary biological terms, is earlier found in his 1918/1925 General Theory of Knowledge (Schlick [1918/1925] 1974, pp. 94-101). Schlick discusses critically the idea that science "serves only the needs of practical foresight" ([1918/1925] 1974, p. 96), clarifying that

\begin{abstract}
the scientist, in pursuing his cognitive goals, fares better if he does not think of practical applications and does not take as the aim of his endeavors the discovery of only practically applicable truths; he should therefore set to work as if truth itself were the final goal. As experience teaches, this is the only way to make the great advances that subsequently prove so fruitful; if when we began we had in mind only what was useful to man, we would never have arrived at such knowledge. But even though it is thus useful for humanity to pretend that truth and pure knowledge constitute the ultimate aim of science, the real goal of cognition nevertheless is actually practical use, which alone provides the struggle for truth with its reason for being. The striving for knowledge 'for its own sake' is merely a game (Schlick [1918/1925] 1974, pp. 96-97, original emphasis).
\end{abstract}

Like earlier in Lebensweisheit, Schlick goes on to note that the type of play that he has in mind is not just a "waste of time" ([1918/1925] 1974, p. 97), but becomes itself a source of pleasure. This takes place after a process of transformation in which, through habituation, what was originally undertaken as a means becomes an end. Play, the product of this transformation, is the pinnacle of human activity: ${ }^{43}$

Speech, at first a means of communication, becomes song; walking, originally a means of getting about, grows into dance; seeing turns into looking- at, hearing into listening-to, work into play. At the apex are those activities connected with play. They alone satisfy immediately, while all

\footnotetext{
${ }^{42}$ Similar claims are found e.g. in Schlick (2013b, pp. 209-210).

${ }^{43}$ See also Tuboly's chapter in this volume for a discussion of the concepts of work and play in Schlick.
} 
behavior that serves simply as means directed to ends - work - acquires value only in relation to the results obtained. ([1918/1925] 1974, p. 97)

In his 1927 "On the Meaning of Life", Schlick further develops the idea of play as exemplifying the meaning of life. There, Schlick explicitly connects his account of play with an insight that he attributes to Nietzsche. In order to do so, Schlick first presents a very compressed summary of his classification of three phases in Nietzsche's work, which he had more extensively developed in his 1912 lectures (see Iven 2013a, pp. 43-46; Ferrari 2016). In 1927, the three stages are presented in terms of Nietzsche's answer to Schopenhauerian pessimism, i.e. as Nietzsche's three replies to the contention that life is meaningless:

\footnotetext{
We know how Nietzsche, for example, sought to conquer this pessimism. First by the flight into art: consider the world, he says, as an aesthetic phenomenon, and it is eternally vindicated! Then by the flight into knowledge: look upon life as an experiment of the knower, and the world will be to you the finest of laboratories! But Nietzsche again turned away from these standpoints; [...] it is hard to reduce to a brief formula what the wisest Nietzsche, the Nietzsche of Zarathustra, saw as the meaning of life. For if it be said that henceforth the ultimate value of life, to him, was life itself that obviously says nothing clear and does not find the right expression for the deep truth which he then perceived or at least suspected. For he saw that life has no meaning, so long as it stands wholly under the domination of purposes [...] In truth, we shall never find an ultimate meaning in existence, if we view it only under the aspect of purpose. (Schlick [1927] 1979, p. 113, original emphasis)
}

In the above passage, Schlick underlines the way in which the way of play traverses all periods in Nietzsche's thinking, remaining a concern both in his positivist valuation of scientific knowledge as the ultimate telos, and his later reconfiguration in terms of the value of life itself (which Schlick thinks is still within the bounds of his earlier anti-metaphysical positivism). Schlick goes on to outline his own positive understanding that follows from such a critique of the exclusive focus on purposive action, namely his idea that the meaning of life is to be found in play, defined as activity undertaken for its own sake, rather than for the sake of the attainment of some other end. Schlick's conception of play as the meaning of life, and not solely connected to the value of knowledge, clearly indicates that he follows Nietzsche into his third period. He remains in agreement with this third phase in Nietzsche even when he presents his conception of play as epitomized by Wissenschaft as 'joyful' (in the Nietzschean sense that we have already seen presented in Lebensweisheit, and which continues to permeate later writings). Thus, as I have demonstrated above, Schlick's 
Nietzschean conception of play remains interconnected with his conception of value-free Wissenschaft throughout his philosophical oeuvre. ${ }^{44}$

\section{XY.9. Philosophy, Wissenschaft, and Politics}

Having clarified Schlick's conceptions of play and value-free Wissenschaft, the question remains: where exactly does Schlick situate philosophy within this picture? Schlick, as we have seen, changes his metaphilosophical views, explicitly resisting the identification of philosophy with Wissenschaft and the pursuit of truth. As e.g. Tuboly's chapter in this volume shows, Schlick had a broader (because more "traditional") conception of the scope of philosophy than some of his fellow Vienna Circle members. Would such an expanded conception of philosophy perhaps allow for some values to creep in?

To answer this, we need to look back to Schlick's analysis of the four stages in the evolution of Wissenschaft, i.e., as already outlined above: 1) pure 'will to pleasure', 2) technological thinking, 3) ('purposeless') games, and 4) games guided by the 'will to truth'. It is clear that the early Schlick has a precise conception of science, which he identifies with (4). But what about philosophy?

As we have already seen, the early Schlick identifies philosophy with the pursuit of truth, and thus with Wissenschaft. Yet this appears to be a prescription rather than a descriptive account of the history of philosophy. In fact, in various passages, the early Schlick contends that not all work that has historically gone under the banner 'philosophy' has attained the level of Wissenschaft in its 'joyful wisdom'. Indeed, sometimes philosophers seem to regress back to the stage preceding the evolution of Wissenschaft, engaging in mere intellectual games instead of the pursuit of truth. When regressing to this stage, according to Schlick, "one cannot deny even the philosophemes of Hegel or Schelling any justification, for in the game it is not so much a question of whether it is meaningful or meaningless" (Schlick [1908] 2006, p. 173).

When people like Hegel or Schelling are playing the game, they are sometimes not guided by the pursuit of truth (even though they designate this as their motivation). Instead, they are simply indulging in 'beautiful nonsense'. Though it is likely that no knowledge will thereby be attained, one could plausibly find pleasure in playing the game of trying to piece together such puzzle, e.g. asking what exactly Hegel might have meant by some combination of words. But even if the game is played for its own sake, the possibility that it might (even

\footnotetext{
${ }^{44}$ Similar claims about the continuation of these Nietzschean themes throughout Schlick's work have also been made by Mormann (2010) and Ferrari (2016).
} 
accidentally) give rise to Wissenschaft is not a priori excluded. For example, Schlick ([1932] 2008b, pp. 400-401) discusses a number of questions that were at first thought by philosophers to be insoluble (and so, in the language of Lebensweisheit, they would remain within the domain of an aimless game), which upon further refinement became scientific questions. Some of Schlick's own work could possibly be thought of in this way, e.g. his views on the meaning of life or the philosophy of youth, which he talks about as undertaken for leisure (Schlick [1927] 1979, 123). ${ }^{45}$ That the game does not have any practical outcome is not in itself a reason to abolish it - but one should, at the same time, not have any expectations of useful outcomes from it, especially in terms of some power to make predictions.

As already outlined above, Schlick changes his metaphilosophical views, rejecting the idea that philosophy is engaged in a scientific pursuit of truth. This is set out most clearly in "The Future of Philosophy", which discusses four conceptions of philosophy, namely:

(i) philosophy as science (i.e. the pursuit of truth),

(ii) philosophy as the 'wisdom of life' (here identified as 'the pursuit of meaning'),

(iii) philosophy as epistemology (i.e. a kind of pursuit of truth about the pursuit of truth), and (iv) philosophy as metaphysics (i.e. as a pursuit of extra-scientific truth).

Schlick explicitly rejects all three conceptions of philosophy as different kinds of pursuit of truth, in preference for what he holds to be a Socratic (Schlick [1932] 2008a, pp. 376, 379380, 383; see also Schlick [1936] 1938, pp. 395-397) and Wittgensteinian (Schlick [1932] 2008a, p. 387) understanding of philosophy as the pursuit of meaning.

Interestingly, the metaphilosophical picture presented here is a kind of reconfiguration of the one we already saw developed in Lebensweisheit, and it is perhaps no accident that Schlick retains the title of 'wisdom of life' for his later conception of philosophy. According to Schlick, the pursuit of meaning is a mental activity of clarification that is a prerequisite for the pursuit of truth. ${ }^{46}$ In order for the scientist to seek for the truth of propositions, the philosopher needs to have played the game in which the meanings of its terms are clarified.

Schlick's conception of the pursuit of meaning is in a sense a regimented version of the playful activity that in Lebensweisheit was presented as coming one stage before the

\footnotetext{
${ }^{45}$ Mormann (2010, p. 265) talks of ethics as the early Schlick's "hobby".

46 'Prerequisite' does not here necessarily imply a temporal precedence - sometimes the truth-value of a statement happens to have been determined before its meaning has been clarified.
} 
evolution of Wissenschaft. In Lebensweisheit, the game of asking questions which have no practical relevance is not regimented. Since it is a kind of free activity, primarily characterized by its being undertaken for its own sake, there is no reason for which to exclude nonsense from it. By contrast, Schlick's regimented version of the game of the pursuit of meaning does include the exclusion of nonsense in its rules. Thus armed with the Vienna Circle's critique of metaphysics, Schlick ([1932] 2008a, 386-387; [1931] 2008c, pp. 301-302) would consign a significant part of the history of philosophy to meaninglessness. Philosophy as the pursuit of meaning is neither the pursuit of truth, nor just any unregimented, aimless intellectual game, but falls somewhere in between the two. ${ }^{47}$ Though Schlick's definition of philosophy as the pursuit of meaning does set a boundary, it is quite a broad one at that (see Tuboly's chapter in this volume). It can thus encompass, for example, the various different projects Schlick was engaged in until the end of his life, including his concern with culture in Nature und Kultur.

The primary change in Schlick's metaphilosophy between 1908 and 1931 is his rigorous differentiation between philosophy and Wissenschaft. What remains the same, however, throughout Schlick's different conceptions of philosophy, is the element of abstention from practical purposes. ${ }^{48}$ Though both may arise from practical concerns, neither the pursuit of truth, nor that of meaning, can be determined by practical ends. Both must be undertaken, in Schlick's conception, for their own sake, as a kind of game. ${ }^{49}$

This explains why Schlick, in 1914, draws a strict line that separates the Idealists' politics from their philosophy. It is also the reason why, in the Nietzsche lectures, Schlick extends this account to make the following claim: once it is conceived in terms of a game undertaken for its own sake (and in 1914 this game is the pursuit of truth, while later it is the pursuit of meaning), philosophy cannot play any political role, let alone the type of political role that it is thought to play in the exaggerated debates about which philosophical idea caused the war. Philosophy, whether as a type of Wissenschaft or as another type of game, presupposes the ability to take a step back from all practical purposes.

\footnotetext{
${ }^{47}$ A large part of the history of what has traditionally been designated as 'philosophy', in Schlick's ([1932] 2008a, 386) view, was simply disguised science. Indeed, as Schlick ([1932] 2008a, p. 388) clarifies, a distinction between philosophy and science comes relatively late in history, and before that, people called 'philosophers' would engage both in the pursuit of truth and the pursuit of meaning. The scientific pursuit of truth and the philosophical pursuit of meaning are two entirely separate games that interact in many important ways.

${ }^{48}$ Elsewhere, for example, Schlick clarifies that, in his conception, philosophy "cannot interfere with science or with human values" ([1932] 2008b, p. 414).

${ }^{49}$ While the earlier separation between Wissenschaft and praxis already sets Schlick apart from Neurath, the designation of a special role for philosophy stands in even more stark opposition to Neurath's conception of Unified Science.
} 
Notice here that the prerequisite disinterested state of mind is at odds with the kind of psychological phenomenon which Schlick had described at the beginning of his lectures. A mind preoccupied with war and the accompanying struggle for survival will have difficulty to undertake the ascent above such practical preoccupations and into a state which plays a game only for its own sake, let alone a state in which it wills only truth. If anything, Schlick (2013a, pp. 85-86) contends, it is an absence of philosophical thinking which allows for the kind of falling back into baser instincts that drives people to war. In Schlick's defense of philosophy against the charge of militarism, he claims that the war is not explained by appeals to the fact

\footnotetext{
that individual nations filled their minds with some philosophy, but at most one could put the blame on the lack of philosophy. All wars, perhaps all conflicts, arise from instincts that are much baser, but more powerful, than the drive to philosophy. And if it were powerful enough to influence people's actions and nations' destinies, then there would perhaps be no wars at all. True philosophy is always peaceful, the spirit of philosophy, which is the spirit of truth, goes hand in hand with the spirit of peace. (Schlick 2013a, pp. 85-86)
}

Thus, in the midst the jingoist turmoil of 1914, we find Schlick arguing that there is a kind of performative contradiction in the appropriation of philosophy for the purposes of warmongering. Philosophy, whether as the pursuit of truth or as the pursuit of meaning, is only possible in peace, insofar as peace makes the pursuit possible.

\section{XY.10. Conclusion}

Many of the leading academic philosophers of Schlick's generation entered into the militaristic frenzy of the first years during the Great War, and at least some of them would later be shunned for this. After the war, Idealism would eventually lose the place it occupied at the forefront of pre-war academic philosophy (see Vrahimis 2015). Since it is unknown if Schlick presented his lectures, it is unclear whether anyone ever actually witnessed Schlick's attempt to intervene in the war controversies. There were, to the best of my knowledge, no public responses to Schlick (as there were to the various other philosophers who intervened in the Idealism controversy). Furthermore, Schlick advocated an apolitical view of philosophy, and did not endorse the squabbling that other academics were involved in. ${ }^{50}$

\footnotetext{
${ }^{50}$ As Mormann (2010) points out, it was this 'political naivety' (p. 272) that led Schlick to the failed attempt to present the Vienna Circle as apolitical so as to accommodate the Austrofascist regime. Schlick even wrote to
} 
Schlick was still in many ways part of the pre-war philosophical establishment (what Ringer calls the 'German mandarins') when he moved to Vienna after the war. ${ }^{51}$ However, due the two factors mentioned above, Schlick would be well-positioned to communicate with scholars who had remained outside this philosophical establishment. ${ }^{52}$ Unlike other philosophers in this establishment, who would have plenty of reasons to regret their wartime defenses of militarism, the outcome of the war gave Schlick no incentive to revise his opinions concerning the apolitical nature of philosophy. On the contrary, he may have felt vindicated in at least thinking about, if not publicly calling for, a philosophical abstinence from the militarist frenzy. This may explain why Schlick would insist on his apolitical stance during the interwar (though e.g., as we have seen, his last unpublished writings did contain criticisms of philosophical positions upheld by the far-right). By contrast with Schlick, the very different war-time experiences of the Vienna Circle's 'left wing' mostly gave them reasons to become more politically active,${ }^{53}$ and even to be less wary of explicitly connecting their political with their philosophical outlooks. This difference at least partly explains their subsequent disagreements concerning the ethical, social, and political consequences of upholding a Wissenschaftliche Weltauffassung. ${ }^{54}$

\section{XY.11. References}

Akehurst, Th. (2010). The Cultural Politics of Analytic Philosophy: Britishness and the Spectre of Europe. London: Continuum.

Anonymous (1915). German spirit due to Kant, not Nietzsche: Professor Dewey traces German Militarism back to the famous Philosopher of the Eighteenth Century and his Categorical Imperative. The New York Times, July 181915.

\footnotetext{
Dollfuß to express his congratulations and sympathy (Stadler 1982, p. 200); see also Stadler 1982, p. 196; Stadler 1991; Hegselmann 2012, pp. 273-274.

${ }^{51}$ Mormann $(2010,284-285)$ claims that Schlick, as opposed to other Vienna Circle members, belonged to this mandarin tradition.

${ }^{52}$ For example, his work on the meaning of life and on the philosophy of youth had some relation to Wyneken's youth movement (itself significantly influenced by Nietzsche); see e.g. Ferrari (2016, p. 8). It is notable that both Carnap and Reichenbach were involved in the youth movement, the latter being active (alongside his friend Walter Benjamin) in Wyneken's group; see e.g. Wolters (Forthcoming).

${ }^{53}$ E.g. in Carnap's autobiography, he says "I have always had an intense interest in moral problems, both those concerning the life of individuals and, since the First World War, those of politics" (Carnap 1963, p. 82); on Carnap's change of heart from his initial militaristic enthusiasm for the war, see Wolters (2017, 18-22; Forthcoming); on Carnap's 'activism', see e.g. Uebel (2012).

${ }^{54}$ How exactly to draw the line between the Vienna Circle's 'left' and 'conservative' wings remains debatable, and I will not attempt to settle the debate here. However one construes the difference, a central issue that is pertinent to it concerns the different conceptions of philosophy's relation to politics that I have explored above. There are, nonetheless, certainly also things that divide the two that are irrelevant to their political disagreements.
} 
Beiser, F.C. (2018). Hermann Cohen: An Intellectual Biography. Oxford: Oxford University Press.

Carnap, R. ([1928] 2003). The Logical Structure of the World and Pseudoproblems in Philosophy. Chicago: Open Court.

Carnap, R. ([1931] 1959a). The Elimination Of Metaphysics Through Logical Analysis of Language. In A.J. Ayer (ed.), Logical Positivism. Glencoe, Illinois: The Free Press, pp. 60-81.

Carnap, R. ([1932] 1959b). Psychology in Physical Language. In A.J. Ayer (ed.), Logical Positivism. Glencoe, Illinois: The Free Press, pp. 165-198.

Carnap, R. (1963). Intellectual Autobiography. In P. A. Schilpp (ed.), The Philosophy of Rudolf Carnap. Illinois: Open Court, pp. 3-83.

Cartwright, N., J. Cat, L. Fleck and Th. Uebel. (1996). Otto Neurath: Philosophy between science and politics. New York: Cambridge University Press.

Dahms, H-J. (1994). Positivismusstreit, Die Auseinandersetzung der Frankfurter Schule mit dem logischen Positivismus, dem amerikanischen Pragmatismus und dem kritischen Rationalismus. Frankfurt: Suhrkamp.

Damböck, Ch. (2017). “Deutscher Empirismus”: Studien zur Philosophie im deutschsprachigen Raum 1830-1930. Dordrecht: Springer.

Damböck, Ch. (2020). (Dis-)Similarities: Remarks on ‘Austrian' and 'German' Philosophy in the 19th Century. In D. Fisette, G. Fréchette and F. Stadler (eds.), Franz Brentano and Austrian Philosophy. Cham: Springer. Forthcoming.

de Warren, N., and Th. Vongehr (eds.) (2018). Philosophers at the Front: Phenomenology and the First World War. Leuven: Leuven University Press.

Feigl, H. ([1952] 1981). Validation and Vindication: An Analysis of the Nature and the Limits of Ethical Arguments. In Inquiries and Provocations: Selected Writings 19291974, Dordrecht: Reidl, pp. 378-392.

Ferrari, M. (2016). Wiener Gefühle. Fragen der Ethik zwischen Schlick und Carnap. In Ch. Bonnet and E. Nemeth (eds.), Wissenschaft und Praxis. Zur Wissenschaftsphilosophie in Frankreich und Österreich in der ersten Hälfte des 20. Jahrhunderts. Dordrecht: Springer, pp. 5-28.

Frank, Ph. ([1917] 1970). 'The Importance of Ernst Mach's Philosophy of Science for our times', in Cohen, Robert S., ed., Ernst Mach: Physicist and Philosopher, Springer, Dordrecht, pp. 219-234. 
Hegel, G.W.F. (2004). Philosophy of Nature: Being Part Two of the Encyclopedia of the Philosophical Sciences. Trans. by Anton V. Miller, Oxford: Clarendon Press.

Hegselmann, R. (1987). Introduction. In B. McGuinness (ed.), Unified Science, Dordrecht: Reidel, pp. ix-xxi, 273-274.

Hoeres, Peter (2004). Der Krieg der Philosophen: Die Deutsche und Britische Philosophie im Ersten Weltkrieg. Paderborn: Schöningh.

Horkheimer, M. ([1937] 1972). The Latest Attack on Metaphysics. In Critical theory:

Selected Essays. New York: Continuum, pp. 132-187.

Iven, M. (2008). Moritz Schlick im Ersten Weltkrieg. Adlershof 1917/18. in F.O. Engler and

M. Iven (eds.), Moritz Schlick. Leben, Werk und Wirkung. Berlin: Parerga, pp. 59-90.

Iven, M. (2013a). Einleitung. In Schlick (2013): pp. 17-52.

Iven, M. (2013b). Editorischer Bericht. In Schlick (2013): pp. 55-76.

James W. (1911). The Moral Equivalent of War. In Memories and Studies, London:

Longmans, Green, and Co., pp. 265-296.

Jeffs, R. (2017). Hegel in Dark Times: The Resurrections of Geist from the Ashes of War. In M. Sharpe, R. Jeffs and J.A. Reynolds (eds.), 100 Years of European Philosophy Since the Great War: Crisis and Reconfigurations. Dordrecht: Springer, pp. 161-182.

Kleinpeter, H. (1913). Der Phenomenalismus: Eine naturwissenschaftliche Weltanschauung. Barth: Leipzig.

Köster, P. (1998). Der verbotene Philosoph: Studien zu den Anfängen der katholischen Nietzsche-Rezeption in Deutschland (1890-1918). Berlin/New York: de Gruyter.

Kusch, M. (1995). Psychologism: A Case Study in the Sociology of Philosophical Knowledge. New York: Routledge.

Lewis, J. (1988). Schlick's Critique of Positivism. PSA: Proceedings of the Biennial Meeting of the Philosophy of Science Association (1): 110-117.

Martin, N. (2006) Nietzsche as Hate-Figure in Britain's Great War: 'The Execrable Neech'. In F. Bridgham (ed.), The First World War as a Clash of Cultures. New York: Camden House, pp. 147-166.

Mormann, Th. (2010). Zwischen Weisheit und Wissenschaft. Schlicks weites philosophisches Spektrum. Grazer Philosophische Studien 80: 263-285.

Mormann, Th. (2015). Review of Moritz Schlick: Nietzsche und Schopenhauer (Vorlesungen). Journal for General Philosophy of Science 46 (2): 419-423.

Mulder, H. (1968). Wissenschaftliche Weltauffassung. Der Wiener Kreis. Journal of the History of Philosophy 6: 386-390. 
Neurath, O. ([1921] 1973). Anti-Spengler. In M. Neurath and R.S. Cohen (eds.) Empiricism and Sociology. Dordrecht: Reidel, pp. 159-213.

Neurath, O. ([1932] 1987). Unified Science and Psychology. In B. McGuinness (ed.), Unified Science. Dordrecht: Reidel, pp. 1-23.

Neurath, O. ([1936] 1981), Die Entwicklung des Wiener Kreises und die Zukunft des Logischen Empirismus. In R. Haller and H. Rutte (eds.) Gesammelte philosophische und methodologische Schriften, Volume 2. Vienna: Hölder-Pichler-Tempsky, pp. 673-703.

Neurath, O. ([1938] 1955). Unified Science as Encyclopedic Integration. In O. Neurath, R. Carnap, Ch. Morris (eds.), International Encyclopedia of Unified Science. Volume I. Part 1, Chicago: University of Chicago Press, pp. 1-27.

Neurath, O. ([1938] 1981). Einheitswissenschaft als Empiristische Synthese. In R. Haller and H. Rutte (eds). Gesammelte philosophische und methodologische Schriften, Volume 2. Vienna: Hölder-Pichler-Tempsky, p. 826.

Neurath, O., and J.A. Lauwerys (1944a). Nazi textbooks and the future: Part 1. The Journal of Education 76 (904): 521-522.

Neurath, O., and J.A. Lauwerys (1944b). Nazi textbooks and the future: Part 2. The Journal of Education 76 (905): 574-576.

Neurath, O., and J.A. Lauwerys (1945). Plato's Republic and German Education. The Journal of Education 77 (907): 57-59.

Nietzsche, F.W. ([1885] 1905). Thus Spoke Zarathustra. Translated by Thomas Common. New York: The Modern Library.

Nietzsche, F.W. (2003). Writings from the Late Notebooks. Edited by R. Bittner, trans. by Kate Sturge. Cambridge: Cambridge University Press.

O’Neil, J., and Th. Uebel (2004). Horkheimer and Neurath: Restarting a Disrupted Debate. European Journal of Philosophy 12 (1): 75-105

Professors of Germany (1919). To the Civilized World. The North American Review 210, 765.

Reisch, G. (2005). How the Cold War Transformed Philosophy of Science: To the Icy Slopes of Logic. Cambridge: Cambridge University Press.

Reynolds, J. (2017). Philosophy and/or Politics? Two Trajectories of Philosophy After the Great War and Their Contamination. In M. Sharpe, R. Jeffs, J. Reynolds (eds.), 100 years of European Philosophy Since the Great War. Philosophical Studies in Contemporary Culture. Cham: Springer, pp. 215-232. 
Richardson, S.S. (2009a). The Left Vienna Circle. Pt. 1: Carnap, Neurath, and the Left Vienna Circle Thesis. Studies in History and Philosophy of Science 40: 14-24.

Richardson, S.S. (2009b). The Left Vienna Circle. Pt. 2: The Left Vienna Circle, Disciplinary History, and Feminist Philosophy of Science. Studies in History and Philosophy of Science 40: $167-174$.

Ringer, F.K. (1969). The Decline of the German Mandarins: The German Academic

Community, 1890-1933. Hanover/London: Wesleyan University Press.

Romizi, D. (2012). The Vienna Circle's “Scientific World-Conception”: Philosophy of Science in the Political Arena. HOPOS: The Journal of the International Society for the History of Philosophy of Science 2 (2): 205-242.

Schleichert, H. (2003). Moritz Schlick's Idea of Non-Territorial States. In F. Stadler (ed.), The Vienna Circle and Logical Empiricism: Re-evaluation and Future Perspectives. Kluwer: Dordrecht, pp. 49-61.

Schlick, M. ([1908] 2006). Lebensweisheit: Versuch einer Glückseligkeitslehre u. Fragen der Ethik. Edited by M. Iven. Dordrecht: Springer.

Schlick, M. ([1918/1925] 1974). General Theory of Knowledge. Transl. by Albert E. Blumberg. New York, Vienna: Springer.

Schlick, M. ([1927] 1979). On the Meaning of Life. In H. L. Mulder and B. F. B. van de Velde-Schlik (eds.), Moritz Schlick: Philosophical Papers: Volume Two (1925-1936). Dordrecht: D. Reidel, pp. 112-129.

Schlick, M. ([1931] 2008c). The Future of Philosophy [1931]. In J. Friedl and H. Rutte (eds.), Die Wiener Zeit: Aufsätze, Beiträge, Rezensionen 1926-1936. Dordrecht: Springer, pp. 297-303.

Schlick, M. ([1932] 2008a). The Future of Philosophy [1932]. In J. Friedl and H. Rutte (eds.), Die Wiener Zeit: Aufsätze, Beiträge, Rezensionen 1926-1936. Dordrecht: Springer, pp. 371-390.

Schlick, M. ([1932] 2008b). A New Philosophy of Experience. In J. Friedl and H. Rutte (eds.), Die Wiener Zeit: Aufsätze, Beiträge, Rezensionen 1926-1936. Dordrecht: Springer, pp. 397-414.

Schlick, M. ([1934] 1959). The Foundation of Knowledge. In A.J. Ayer (ed.), Logical Positivism. Transl. by David Rynin. Glencoe, Illinois: The Free Press, pp. 209-227. Schlick, M. ([1936] 1938), L’École de Vienne et la Philosophie traditionnelle. Gesammelte Aufsätze 1926-1936, Vienna: Gerold \& Co., pp. 389-398.

Schlick, M. (1952). Natur und Kultur. Vienna-Stuttgard: Humbold. 
Schlick, M. (1962). Aphorismen. Edited by Blanche Hardy Schlick. Vienna: Carl Ueberreuter.

Schlick, M. (2013a). Nietzsche und Schopenhauer. Edited by M. Iven. Dordrecht: Springer.

Schlick, M. (2013b). Erkentnisstheoretische Schriften, 1926-1936. Edited by Johannes Friedl and Heiner Rutte. Dordrecht: Springer.

Siegetsleitner, A. (2010). Schlicks Fragen der Ethik und die vorherrschende Sicht logischempiristischer Ethik. In A. Siegetsleitner (ed.), Logischer Empirismus, Werte und Moral. Vienna: Springer, pp. 9-19.

Sombart, W. (1915). Händler und Helden: Patriotische Besinnungen. Munich/Leipzig: Duncker \& Humblot.

Soulez, A. (2019). Does Understanding Mean Forgiveness? Otto Neurath and Plato's "Republic" in 1944-45. In J. Cat and A.T. Tuboly (eds), Neurath Reconsidered: New Sources and Perspectives, Dordrecht: Springer, pp. 435-449.

Stadler, F. (1982). Vom Positivismus zur “wissenschaftlichen Weltauffassung." Vienna: Löcker.

Stadler, F. (1991). Otto Neurath-Moritz Schlick: On the Philosophical and Political Antagonisms in the Vienna Circle. In Th. Uebel (ed.), Rediscovering the Forgotten Vienna Circle: Austrian Studies on Otto Neurath and the Vienna Circle, 159-168, Dordrecht: Kluwer, pp. 159-168.

Stewart, H. L. (1915), Nietzsche and the Ideals of Modern Germany. London: Edward Arnold.

Textor, M. (2018). Schlick on the Source of the 'Great Errors in Philosophy'. Journal of the American Philosophical Association 4 (1): 105-125.

Thomas, R.H. (1983). Nietzsche in German Politics and Society, 1890-1918. Manchester: Manchester University Press.

Tuboly, A. T. (2020a). A cricket game, a train ticket and a vacuum to be filled: Ayer's logical positivism as a focal point for post-war British cultural struggles. British Journal for the History of Philosophy. Online First.

Tuboly, Adam Tamas. (2020b). Neurath on Plato-Hitler and the British Scene of Irritation. In Ch. Damböck, J. Friedl, and U. Höfer (eds.), Proceedings of the Carnap/Neurath Conference. Studien zur Österreichischen Philosophie. Rodopi/Brill. Forthcoming. Tuusvuori, J. S. (2000). Nietzsche \& Nihilism: Exploring a Revolutionary Conception of Philosophical Conceptuality. PhD Dissertation, University of Helsinki. 
Uebel, Th. (2005). Political Philosophy of Science in Logical Empiricism: the Left Vienna Circle. Studies in History and Philosophy of Science 36: 754-763.

Uebel, Th. (2007). Empiricism at the Crossroads. The Vienna Circle's Protocol Sentence Debate. Chicago: Open Court.

Uebel, Th. (2008). Writing a Revolution: On the Production and Early Reception of the Vienna Circle's Manifesto. Perspectives on Science 16 (1): 70-102.

Uebel, Th. (2010). What's Right about Carnap, Neurath and the Left Vienna Circle Thesis: A Refutation. Studies in History and Philosophy of Science 41: 214-221.

Uebel, Th. (2012). Carnap, Philosophy, and "Politics in its Broadest Sense". In R. Creath (ed.), Rudolf Carnap and the Legacy of Logical Empiricism. Dordrecht: Springer, pp. 133148.

Uebel, Th. (2020). Schlick and Wittgenstein: The Theory of Affirmations Revisited. Journal of the History of Philosophy 58 (1): 141-166.

Voegelin, E. (1944). Nietzsche, the Crisis and the War. The Journal of Politics 6 (2): 177212.

Von Mises, R. ([1938] 1987). Ernst Mach and the Scientific Conception of the World. In B. McGuinness (ed.), Unified Science. Dordrecht: Reidel, pp. 166-190.

Vrahimis, A. (2011). Russell's critique of Bergson and the divide between "Analytic" and “Continental” Philosophy. Balkan Journal of Philosophy 3 (1): pp. 123-134.

Vrahimis, A. (2013). Encounters between Analytic and Continental Philosophy. Basingstoke: Palgrave Macmillan.

Vrahimis, A. (2015). Legacies of German Idealism: From the Great War to the AnalyticContinental divide. Parrhesia 24: 83-106.

Vrahimis, A. (2019). The Analytic-Continental divide and the question of Philosophy's relation to Literature. Philosophy and Literature 43 (1): 253-269.

Vrahimis, A. (2020a). Scientism, Social Praxis, and overcoming Metaphysics: A debate between Logical Empiricism and the Frankfurt School, HOPOS: The Journal of the International Society for the History of Philosophy of Science 10 (2). Forthcoming. Vrahimis, A. (2020b). The Vienna Circle's responses to Lebensphilosophie. Logique et Analyse. Forthcoming.

Vrahimis, A. (2020c) Russell reads Bergson. In M. Sinclair and Y. Wolf (eds.), The Bergsonian Mind. Oxon: Routledge. Forthcoming.

Waismann F. (1994a). Ethics and Science. In B. McGuinness and J. Schulte (eds.), Ethics and the Will. Dordrecht: Springer, pp. 33-52. 
Waismann F. (1994b). Will and Motive. In B. McGuinness and J. Schulte (eds.), Ethics and the Will. Dordrecht: Springer, pp. 53-137.

Windsor, T. (2014). Rekindling Contact: Anglo-German Academic Exchange after the First World War. In H. Ellis and U. Kirchberger (eds.), Anglo-German Scholarly Networks in the Long Nineteenth Century. Leiden/Boston: Brill, pp. 212-231.

Wolters, G. (2017). Clash of Cultures? - German Philosophers of Science and the Great War (1914-1918). Bollettino della Società Filosofica Italiana 220: 7-28.

Wolters, G. (Forthcoming). Philosophenkrieger? - Wie Carnap \& Co den Ersten Weltkrieg sahen. In Ch. Damböck, G. Sandner, and M. Werner (eds.), Logical Empirism, Life Reform, and the German Youth Movement. Cham: Springer. 